\title{
Growth and Development of Oenothera fruticosa Is Influenced by Vernalization Duration, Photoperiod, Forcing Temperature, and Plant Growth Regulators
}

\author{
Emily A. Clough, ${ }^{1}$ Arthur C. Cameron, ${ }^{2}$ Royal D. Heins, ${ }^{2}$ and William H. Carlson ${ }^{2}$ \\ Department of Horticulture, Michigan State University, East Lansing, MI 48824
}

AdDitional INDEX wORDs. herbaceous perennials, sundrops, ancymidol, chlormequat, daminozide, paclobutrazol, uniconazole

\begin{abstract}
AвstRact. Influences of vernalization duration, photoperiod, forcing temperature, and plant growth regulators (PGRs) on growth and development of Oenothera fruticosa L. 'Youngii-lapsley' ('Youngii-lapsley' sundrops) were determined. Young plants were vernalized at $5{ }^{\circ} \mathrm{C}$ for $0,3,6,9,12$, or 15 weeks under a 9-hour photoperiod and subsequently forced in a 20 ${ }^{\circ} \mathrm{C}$ greenhouse under a 16-hour photoperiod. Only one plant in 2 years flowered without vernalization, while all plants flowered after receiving a vernalization treatment, regardless of its duration. Thus, $O$. fruticosa had a nearly obligate vernalization requirement. Time to visible bud and flower decreased $b y \approx 1$ week as vernalization duration increased from 3 to 15 weeks. All plants flowered under 10-, 12-, 13-, 14-, 16-, or 24-hour photoperiods or a 4-hour night interruption (NI) in a $20^{\circ} \mathrm{C}$ greenhouse following 15 -weeks vernalization at $5^{\circ} \mathrm{C}$. Time to flower decreased by $\approx 2$ weeks, flower number decreased, and plant height increased as photoperiod increased from 10 to 16 hours. Days to flower, number of new nodes, and flower number under 24 hour and NI were similar to that of plants grown under a 16-hour photoperiod. In a separate study, plants were vernalized for 15 weeks and then forced under a 16-h photoperiod at 15.2, 18.2, 20.6, 23.8, 26.8, or 29.8 ${ }^{\circ} \mathrm{C}$ (average daily temperatures). Plants flowered 35 days faster at $29.8^{\circ} \mathrm{C}$ but were $18 \mathrm{~cm}$ shorter than those grown at 15.2 ${ }^{\circ} \mathrm{C}$. In addition, plants grown at $29.8^{\circ} \mathrm{C}$ produced only one-sixth the number of flowers (with diameters that were $3.0 \mathrm{~cm}$ smaller) than plants grown at $15.2^{\circ} \mathrm{C}$. Days to visible bud and flowering were converted to rates, and base temperature $\left(T_{b}\right)$ and thermal time to flowering (degree-days) were calculated as $4.4^{\circ} \mathrm{C}$ and $606{ }^{\circ}$ days, respectively. Effects of foliar applications of ancymidol $\left(100 \mathrm{mg} \cdot \mathrm{L}^{-1}\right)$, chlormequat $\left(1500 \mathrm{mg} \cdot \mathrm{L}^{-1}\right)$, paclobutrazol $\left(30 \mathrm{mg} \cdot \mathrm{L}^{-1}\right)$, daminozide $\left(5000 \mathrm{mg} \cdot \mathrm{L}^{-1}\right)$, and uniconazole $\left(15 \mathrm{mg} \cdot \mathrm{L}^{-1}\right)$ were determined on plants vernalized for 19 weeks and then forced at $20{ }^{\circ} \mathrm{C}$ under a 16-h photoperiod. Three spray applications of uniconazole reduced plant height at first flower by $31 \%$ compared with that of nontreated controls. All other PGRs did not affect plant growth. Chemical names used: $\alpha$-cyclopropyl- $\alpha-(4-m e t h o x y p h e n y l)-$ 5-pyrimidinemethanol (ancymidol); (2-chloroethyl) trimethylammonium chloride (chlormequat); butanedioic acid mono(2,2-dimethyl hydrazide) (daminozide); $(2 R, 3 R+2 S, 3 S)-1-(4-c h l o r o p h e n y l-4,4-d i m e t h y l-2-[1,2,4-t r i a z o l-1-y l])$ (paclobutrazol); (E)-(S)-1-(4-chlorophenyl)-4,4-dimethyl-2-(1,2,4-triazol-1-yl)-pent-1-ene-3-ol (uniconazole).
\end{abstract}

Many species of Oenothera L. have been cultivated since the early 1800 s when they were brought from North and South America to England, where they became popular garden plants (Wiesner, 1991). Oenothera fruticosa, or sundrops, is native to eastern North America and hardy in USDA zones 4 through 8. It typically flowers in June (Griffiths, 1994; Nau, 1996) and spreads by underground lateral shoots that appear shortly after flowering. In a preliminary screen, the vegetatively propagated 'Youngii-lapsley' showed great potential as a potted flowering plant, with its relatively long natural flowering time of up to 4 weeks and numerous large bright-yellow flowers (Frane, 1999). To our knowledge, O. fruticosa is not grown currently as a flowering potted plant and there is no published information on flower-induction requirements.

Flowering of many herbaceous perennials is influenced by vernalization and photoperiod (Iversen and Weiler, 1994; Runkle et al., 1998; Whitman et al., 1996,1997). Vernalization can be defined as the promotion of flower formation by a period of low temperatures, generally between -5 and $15{ }^{\circ} \mathrm{C}$, with a broad optimum between 1 and $7{ }^{\circ} \mathrm{C}$ (Lang, 1965). In some species, a vernalization requirement can be linked to a subsequent photoperiod requirement (Vince-Prue, 1975). The role of vernalization and photoperiod in

Received for publication 3 Apr. 2000. Accepted for publication 29 Dec. 2000. We gratefully acknowledge support of the Michigan Agricultural Experiment Station and funding by greenhouse growers supportive of Michigan State University floricultural research. The cost of publishing this paper was defrayed in part by the payment of page charges. Under postal regulations, this paper therefore must be hereby marked advertisement solely to indicate this fact.

${ }^{1}$ Former graduate student.

${ }^{2}$ Professor. flowering of various Oenothera species has been studied, and several different response types have been identified (Takimoto, 1985). Picard (1965) observed flowering of O. biennis var. sulfurea De Vries only after $>10$ weeks of treatment at $11^{\circ} \mathrm{C}$ days $/ 3^{\circ} \mathrm{C}$ nights $(\mathrm{D} / \mathrm{N})$ followed by photoperiods $\geq 12 \mathrm{~h}$. Many species of Oenothera, including O. suaveolens Pers., O. longiflora L., and O. stricta Lebed. ex Link, have facultative requirements for vernalization followed by an obligate requirement for long days (Chouard, 1960). Oenothera rosea L'Herit. ex Ait. is a facultative long-day plant with no response to vernalization (Chouard, 1960). In an initial screen, 'Youngii-lapsley' sundrops appeared to be a facultative long-day plant with an obligate vernalization requirement (Frane, 1999).

The effect of temperature on plant development rate is important to accurately time crop production, although to our knowledge there is no published timing information available for $O$. fruticosa. The relationship between temperature and rate of development toward flowering can be used to estimate the base temperature $\left(T_{b}\right)$ and the number of units (degree-days) of thermal time above a base temperature required for flowering (Roberts and Summerfield, 1987).

Growing temperature can affect plant appearance as well as flower timing. For Antirrhinum majus L. 'Jackpot' ('Jackpot' snapdragon), there was a decrease in stem length, inflorescence length, and number of florets as temperature increased from 10 to 21 ${ }^{\circ} \mathrm{C}$ (Maginnes and Langhans, 1961). Flower size decreased with increasing temperature in Galinsoga parviflora Cavan., Agrostemma githago L. (Knapp, 1957); Campanula carpatica Jacq. 'Blue Clips' (Whitman et al., 1997), Gaillardia $\times$ grandiflora Van Houtte 'Goblin', Leucanthemum $\times$ superbum Bergman ex J. Ingram 'Snowcap' ('Snowcap' Shasta daisy), Coreopsis grandiflora Hogg ex Sweet 
'Sunray' ('Sunray' tickseed), and Rudbeckiafulgida Ait. 'Goldsturm' (Yuan et al., 1998).

A potential problem in growing $O$. fruticosa 'Youngii-lapsley' as a potted flowering plant is its relatively tall natural height (33 to $54 \mathrm{~cm}$ ). Control of height by plant growth regulator (PGR) treatment may be required to produce high-quality potted plants. Although we have been unable to find any previous reports on the effect of PGRs on $O$. fruticosa, single applications of up to $3000 \mu \mathrm{g}$ of chlormequat per pot to the root zone of chilled $O$. biennis plants reportedly had no effect on stem elongation or flowering (Pickard, 1967).

The objectives of this study were to determine and quantify the 1) vernalization and photoperiod requirements for growth and flowering, 2) effects of growing temperature on timing and flower quality, and 3) effect of five commercially available PGRs on plant height at first flower for $O$. fruticosa 'Youngii-Lapsley'.

\section{Materials and Methods}

General. Oenothera fruticosa 'Youngii-lapsley' were received as rooted stem cuttings in 72-cell plug trays on 29 Oct. 1997 (Year 1) and 23 Sept. 1998 (Year 2) from the same commercial producer. Initial nodes were not counted in Year 1; in Year 2, the starting plants were uniform and averaged 18.0 $\pm 0.2(\mathrm{SD})$ nodes. Plants were held in plug trays and exposed to natural day lengths (lat. $43^{\circ} \mathrm{N} ; \approx 11$ to $12 \mathrm{~h}$ ) for 2 or $5 \mathrm{~d}$ (Year 1 or 2 , respectively) until the experiments began. Vernalization treatments were provided to plants held in plug trays in controlled-environment coolers at $5 \pm 0.2^{\circ} \mathrm{C}$ with irradiation for $9 \mathrm{~h} \cdot \mathrm{d}^{-1}$ from cool-white fluorescent lamps (F96T12/CW/VHO, Philips, Somerset, N.J.) at 10 to $20 \mu \mathrm{mol} \cdot \mathrm{m}^{-2} \cdot \mathrm{s}^{-1}$ measured at canopy height using a quantum sensor (LI-189; LI-COR, Inc., Lincoln, $\mathrm{Neb}$.). Plugs were watered as necessary (about two times per week) by using well water acidified to a $\mathrm{pH}$ of $\approx 6.0$ with sulfuric acid $(93 \%$ $\mathrm{H}_{2} \mathrm{SO}_{4}$ ).

Before placement in the greenhouses, plugs were transplanted into $13-\mathrm{cm}$ square plastic pots (1.1-L volume) with a soilless medium containing sphagnum peat, composted pine bark, vermiculite, and perlite (Strong-Lite High Porosity Mix, Strong-Lite, Pine Bluff, Ark.). Pots were spaced at 22 plants $/ \mathrm{m}^{2}$. Plants were fertilized at every irrigation with a nutrient solution of well water [electrical conductivity (EC) of $0.70 \mathrm{dS} \cdot \mathrm{m}^{-1}$ and 105,35 , and $23\left(\mathrm{mg} \cdot \mathrm{L}^{-1}\right) \mathrm{Ca}$, $\mathrm{Mg}$, and $\mathrm{S}$, respectively] acidified with $\mathrm{H}_{2} \mathrm{SO}_{4}$ to a titratable $\mathrm{CaCO}_{3}$ alkalinity of $130 \mathrm{mg} \cdot \mathrm{L}^{-1}$. When supplemented with water-soluble fertilizers, this regime provided $125,12,125$, and $13 \mathrm{mg} \cdot \mathrm{L}^{-1} \mathrm{~N}, \mathrm{P}, \mathrm{K}$, and $\mathrm{Ca}$, respectively, with $30 \%$ ammoniacal $\mathrm{N}$ and minor elements. The target ranges for $\mathrm{EC}$ and $\mathrm{pH}$ were 0.5 to $1.2 \mathrm{dS} \cdot \mathrm{m}^{-1}$ and 5.8 to 6.2 , respectively, using a 2 water : 1 medium test procedure. The second year, it was necessary to drench all plants transplanted after 1 Jan. 1999 twice with a soluble fertilizer containing $\mathrm{N}$ at 750 $\mathrm{mg} \cdot \mathrm{L}^{-1}$ and $\mathrm{KHCO}_{3}$ at $7.2 \mathrm{~g} \cdot \mathrm{L}^{-1}$ to raise the $\mathrm{pH}$ and $\mathrm{EC}$ to the desired ranges.
GREENHOUSE TEMPERATURE CONTROL ANDDAILY LIGHT INTEGRAL COLLECTION. Air temperatures were monitored on all benches in each greenhouse with 36 -gauge $(0.127$-mm-diameter) thermocouples connected to a datalogger (CR 10; Campbell Scientific, Logan, Utah). The datalogger collected temperature data every $10 \mathrm{~s}$ and recorded the hourly average. Average daily air temperatures (ADTs) from transplant to average date of flowering were calculated for every treatment in each experiment and were used in all analyses. Temperatures in each greenhouse were controlled by an environmental computer (model CD750; Priva, De Lier, The Netherlands).

Light was measured at canopy level by using a quantum sensor (model LI-189) connected to the datalogger. The datalogger collected light data every $10 \mathrm{~s}$ and recorded the hourly average. Average daily light integrals (DLI) were calculated from planting to first flower. Light data were collected only in Year 2 for the vernalization experiment.

Vernalization DURATion (EXPT. 1). Plants in plug trays were vernalized at $5^{\circ} \mathrm{C}$ for $0,3,6,9,12$, or 15 weeks. Experiments were initiated 31 Oct. 1997 (Year 1) and 28 Sept. 1998 (Year 2). Ten plants were removed from the cooler after each vernalization duration, transplanted, and grown in a greenhouse under a 16-h photoperiod. Measured average daily air temperatures (Years 1 and 2 ) and average DLI (Year 2 only) from the date of transplant to the average date of flowering are given in Table 1 for each vernalization duration. Photoperiodic and supplemental lighting were provided daily by 400-W high-pressure sodium lamps (HPS) between 0800 and $0000 \mathrm{HR}$. The HPS lamps delivered a photosynthetic photon flux $(P P F)$ of $50 \mu \mathrm{mol} \cdot \mathrm{m}^{-2} \cdot \mathrm{s}^{-1}$ at plant height. The lamps stayed on until the outside $P P F$ exceeded $400 \mu \mathrm{mol} \cdot \mathrm{m}^{-2} \cdot \mathrm{s}^{-1}$. If the outside $P P F$ then dropped below $200 \mu \mathrm{mol} \cdot \mathrm{m}^{-2} \cdot \mathrm{s}^{-1}$, lamps were again turned on until $2200 \mathrm{HR}$

Photoperiod (EXPT. 2). Seven photoperiods [10, 12, 13, 14, 16, and $24 \mathrm{~h}$ and a 4-h night interruption (NI)] and two vernalization treatments ( 0 or 15 weeks) were tested. No plants flowered without vernalization, and only data from after vernalization are presented. Plants were vernalized in plug trays at $5 \pm 0.2^{\circ} \mathrm{C}$ as described above. Vernalized plants were transplanted on 18 Feb. 1998 (Year 1) and 12 Jan. 1999 (Year 2) and placed in a greenhouse under each of the seven photoperiod treatments. Photoperiods were assigned randomly each year to greenhouse benches. Actual average daily air temperatures from the date of transplant to the average date of flowering for both years are given in Table 2 for each photoperiod. Each year, there were 10 plants per photoperiod treatment.

Opaque blackcloth was pulled at $1700 \mathrm{HR}$ and opened at $0800 \mathrm{HR}$ every day on all benches so all plants under each photoperiodic treatment received a similar DLI. Starting at $1700 \mathrm{HR}$, photoperiods were delivered by day-extension lighting with incandescent lamps that were turned off after each photoperiod was completed. The 4$\mathrm{h}$ NI was provided by incandescent lamps that were turned on at $2200 \mathrm{HR}$ and off at $0200 \mathrm{HR}$. Day-extension and NI lighting with

Table 1. Average daily air temperatures and daily light integrals from date of transplant to average date of flowering for Oenothera fruticosa 'Youngiilapsley' after each vernalization duration. Light data measurements were made only in 1998-99.

\begin{tabular}{|c|c|c|c|c|c|c|}
\hline \multirow[b]{2}{*}{ Year } & \multicolumn{6}{|c|}{ Vernalization duration at $5^{\circ} \mathrm{C}$ (weeks) } \\
\hline & 0 & 3 & 6 & 9 & 12 & 15 \\
\hline & \multicolumn{6}{|c|}{ Avg air temp during forcing $\left({ }^{\circ} \mathrm{C}\right)$} \\
\hline 1997-98 & 19.9 & 20.0 & 19.7 & 19.7 & 19.9 & 20.2 \\
\hline \multirow[t]{2}{*}{ 1998-99 } & $--^{\mathrm{z}}$ & 21.1 & 20.9 & 20.1 & 20.3 & 20.8 \\
\hline & \multicolumn{6}{|c|}{ Avg daily light integral $\left(\mathrm{mol} \cdot \mathrm{m}^{-2} \cdot \mathrm{d}^{-1}\right)$} \\
\hline 1998-99 & --- & 12.6 & 11.2 & 10.6 & 10.6 & 11.6 \\
\hline
\end{tabular}

${ }^{\mathrm{z} N o}$ plants flowered. 
Table 2. Average daily air temperatures from date of transplant to average date of flowering for Oenothera fruticosa 'Youngii-lapsley' under each photoperiod. Temperature and light were monitored on each bench every $10 \mathrm{~s}$ during the growing period.

\begin{tabular}{|c|c|c|c|c|c|c|c|c|}
\hline \multirow[b]{2}{*}{ Year } & \multirow{2}{*}{$\begin{array}{c}\text { Vernalization } \\
\text { duration } \\
\text { at } 5^{\circ} \mathrm{C} \\
\text { (weeks) }\end{array}$} & \multicolumn{7}{|c|}{ Photoperiod (h) } \\
\hline & & 10 & 12 & 13 & 14 & 16 & 24 & $\mathrm{NI}^{2}$ \\
\hline & & \multicolumn{7}{|c|}{ Avg air temp during forcing $\left({ }^{\circ} \mathrm{C}\right)$} \\
\hline 1997-98 & 15 & 21.1 & 20.8 & 20.6 & 21.9 & 21.8 & 21.1 & 21.1 \\
\hline 1998-99 & 15 & 21.0 & 20.8 & 20.7 & 20.9 & 20.6 & 21.1 & 21.2 \\
\hline
\end{tabular}

z9-h photoperiod plus 4-h night interruption (NI).

incandescent lamps provided 1 to $3 \mu \mathrm{mol} \cdot \mathrm{m}^{-2} \cdot \mathrm{s}^{-1}$ at canopy level. Supplemental lighting was provided by HPS lamps that delivered $\approx 50 \mu \mathrm{mol} \cdot \mathrm{m}^{-2} \cdot \mathrm{s}^{-1}$ at canopy level between $0800 \mathrm{HR}$ and $1700 \mathrm{HR}$.

Forcing TEMPERATURE (EXPT. 3). Starting 28 Sept. 1998, plants in plug trays were vernalized at $5^{\circ} \mathrm{C}$, as described above for 15 weeks until 12 Jan. 1999, when they were transplanted. At transplant, plants averaged 19.4 leaves. Ten plants were placed into each of six greenhouses set to $14,17,20,23,26$, or $29^{\circ} \mathrm{C}$. Measured ADTs from transplant to visible bud and from visible bud to flower were similar and averaged 15.2, 18.2, 20.6, 23.6, 26.8, and $29.8^{\circ} \mathrm{C}$. Temperatures were carefully controlled; the greatest difference between ADT during days to visible bud and days from visible bud to flower at any temperature setting was $0.4^{\circ} \mathrm{C}$. From 0800 to 0000 HR each day, continual 16-h photoperiod was delivered by HPS lamps that provided $\approx 90 \mu \mathrm{mol} \cdot \mathrm{m}^{-2} \cdot \mathrm{s}^{-1}$ at plant height.

Plant growth Regulators (EXPT. 4). Five commercially available plant growth regulators (PGRs) were tested for their ability to control plant height. The PGRs and rates tested included ancymidol at $100 \mathrm{mg} \cdot \mathrm{L}^{-1}$ (Sepro, Carmel, Ind.), chlormequat at $1500 \mathrm{mg} \cdot \mathrm{L}^{-1}$ (American Cyanamid Co., Wayne, N.J.), daminozide at $5000 \mathrm{mg} \cdot \mathrm{L}^{-}$ 1 (Uniroyal, Middlebury, Conn.), paclobutrazol at $30 \mathrm{mg} \cdot \mathrm{L}^{-1}$ (Uniroyal, Middlebury, Conn.), and uniconazole at $15 \mathrm{mg} \cdot \mathrm{L}^{-1}$ (Valent, Walnut Creek, Calif.). Plants were given a 19-week vernalization treatment at $5^{\circ} \mathrm{C}$ and on 6 Feb. 1999 were transplanted into 1.1-L containers and placed in a greenhouse set at $20^{\circ} \mathrm{C}$. A $16-\mathrm{h}$ photoperiod was provided by HPS lamps, as described for Expt. 1. The actual daily average air temperature between transplant and average date of flowering was $20.6^{\circ} \mathrm{C}$, and the average daily light integral from transplant to first open flower was $14.9 \mathrm{~mol} \cdot \mathrm{m}^{-2} \cdot \mathrm{d}^{-1}$. Plants were allowed to establish for $10 \mathrm{~d}$ before the first PGR spray. For each growth retardant, eight plants were sprayed until the solution dripped off the leaves $(\approx 3 \mathrm{~mL}$ per plant). Following the first spray, plants were sprayed every $10 \mathrm{~d}$ until the first flower opened. In total, each PGR was applied to a plant three times. Eight plants were not sprayed with any chemical and served as the control.

Data COllection AND ANALYSIS. The data collected for all experiments included date of first visible flower bud (without dissection) and date of first open flower. Days to visible bud, days to flower, and days from visible bud to flower were calculated for each plant in all experiments. At first open flower, plant height (excluding the container) and number of visible flowers and buds were recorded. In Year 2, both the initial number of nodes and final number of nodes (counted to the last visible leaf) were recorded. The number of new nodes produced during forcing was calculated by subtracting the initial number of leaves from the final number of leaves. The number of lateral shoots and flowering lateral shoots was recorded for Expts. 1 and 2 in Year 2 only. Flower diameter was recorded for Expts. 3 and 4. For all experiments, plants that did not have visible buds after 15 weeks of forcing were considered nonflowering and were discarded. The few plants that died during the experiment were discarded and not included in the results or calculations.

All experiments were completely randomized designs. Data were analyzed by using the general linear models procedure (SAS Inst., Cary, N.C.) for analysis of variance and linear regression procedure for regression models. Duncan's multiple range test was used to analyze the PGR experiment (Expt. 4) because of the discontinuous nature of the treatments. The vernalization duration and photoperiod experiments (Expts. 1 and 2, respectively) were replicated in time and the years were used as replications.

\section{Results and Discussion}

VERNALIZATIONDURATION(EXPT. 1). Horticulturally, $O$. fruticosa 'Youngii-lapsley' had an obligate vernalization requirement. Without a vernalization treatment, only one out of 10 plants flowered in Year 1 and no plants flowered in Year 2 (Fig. 1A). This single plant was the only one that flowered without vernalization in any of our experiments (one out of 180 plants tested without vernalization), and its flowering behavior was quite different from that of all other plants examined. It flowered 42 to 54 d slower (Fig. 1B), produced 47 to 55 more nodes (data not shown), was 23 to $34 \mathrm{~cm}$ shorter (Fig. $1 \mathrm{D})$, and produced $\approx 25 \%$ the number of flowers that other plants did for Year 1 (Fig. 1A). When grown outdoors, lateral shoots of $O$. fruticosa 'Youngii-lapsley' occasionally formed flowers in August in large plantings (personal observations). Thus, botanically, the vernalization requirement is nearly but not completely obligate.

Three weeks was adequate to fulfill the vernalization requirement for $O$. fruticosa 'Youngii-lapsley'. As vernalization duration increased from 3 to 15 weeks, there was only a half-day decrease in time to visible bud and flower for every subsequent week of vernalization (Fig. 1B). It took $19 \mathrm{~d}$ to go from visible bud to open flower, and this time was not affected by the vernalization duration (Fig. 1B). The number of new nodes produced during forcing decreased linearly at less than one node per week with increasing vernalization duration (Fig. 1C). This result correlated with the small decrease in time to flower $\left(r^{2}=0.37 ; P \leq 0.01\right)$. Plant height increased with vernalization durations up to 9 weeks but decreased after longer vernalization durations (Fig. 1D). Plants in Year 2 were $11 \mathrm{~cm}$ shorter than those grown in Year 1 over all vernalization durations. All vernalized plants, independent of duration, produced $\approx 10$ lateral branches, and $65 \%$ of these lateral branches formed flowers. The number of flowers and buds counted at first open flower increased linearly with vernalization duration, with about six more flowers for every additional week of vernalization (Fig. 1E).

Photoperiod (EXPT. 2). Oenothera fruticosa 'Youngii-Lapsley' can be classified as a facultative long-day plant. After a 15 -week vernalization period, all plants flowered under all photoperiods. Days to flower and to visible bud decreased linearly as photoperiod increased from 10 to $16 \mathrm{~h}$, but there was no further change as 

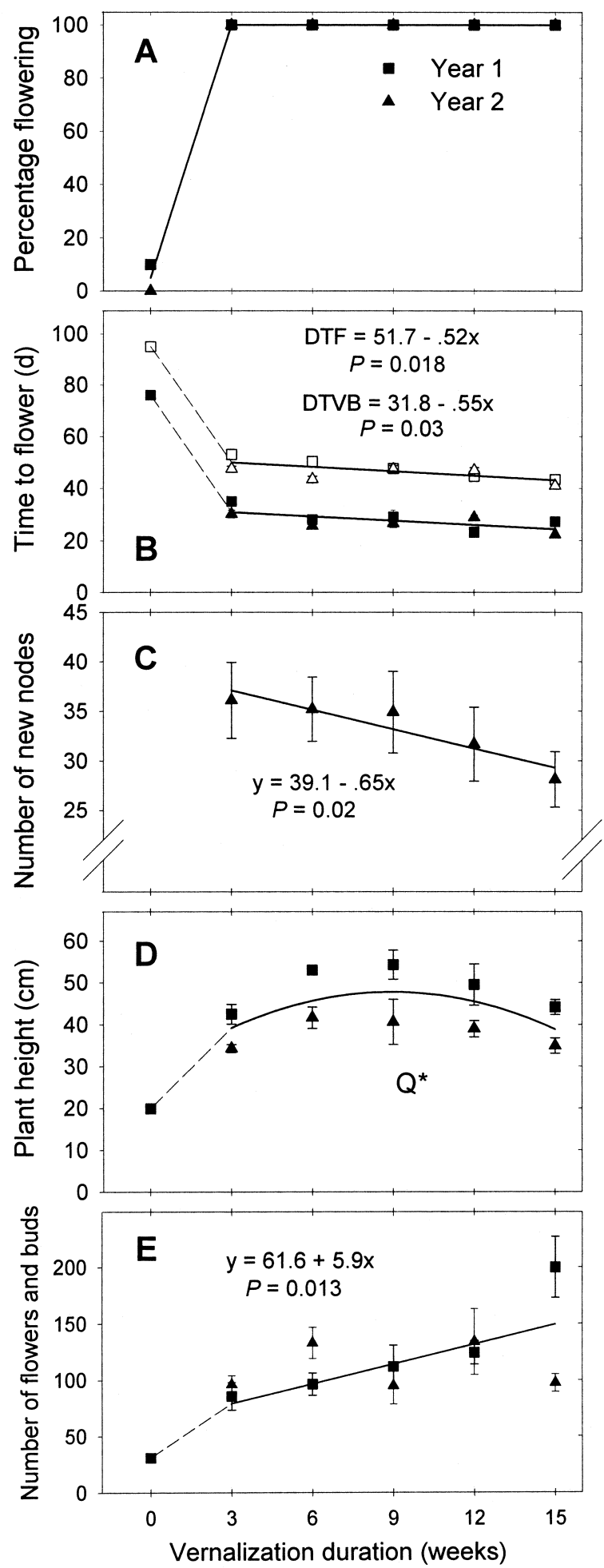

Fig. 1. Regrowth and flowering of Oenothera fruticosa 'Youngii-lapsley' in response to increasing vernalization duration at $5{ }^{\circ} \mathrm{C}$ (Expt. 1). Squares and triangles represent data from Year 1 and Year 2, respectively. In B, open symbols denote days to flower (DTF); closed symbols, days to visible bud (DTVB). Data presented in C, D, and E were collected when the first flower opened on each plant. Except for 0 weeks vernalization, each symbol is based on 10 observations. Vertical bars represent $95 \%$ confidence intervals, and, when smaller than symbols, are not shown. Regression analysis did not include data from 0 weeks vernalization. $\mathrm{Q}^{*}=$ quadratic trend significant at $P \leq 0.05$.

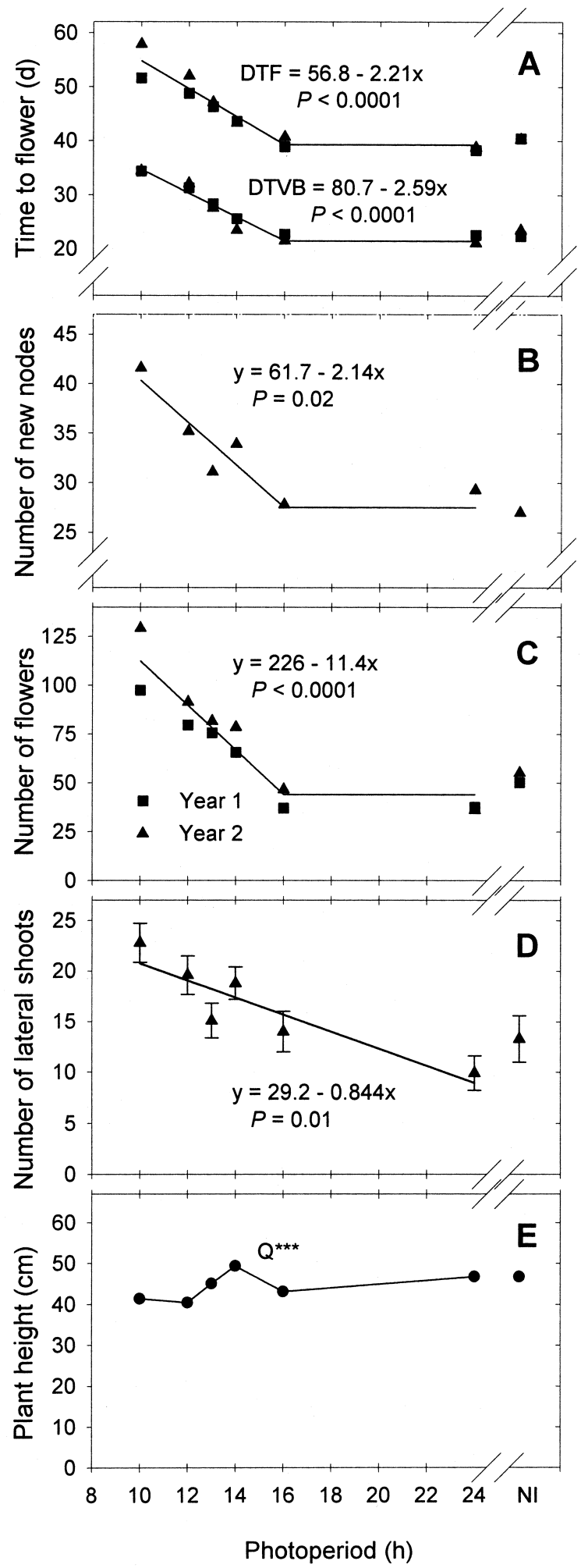

Fig. 2. Regrowth and flowering of Oenothera fruticosa 'Youngii-lapsley' to various photoperiods after 15 weeks of vernalization at $5{ }^{\circ} \mathrm{C}$ (Expt. 2). Squares and triangles represent data from Year 1 and Year 2, respectively. In A, upper graph is days to flower (DTF); lower graph is days to visible bud (DTVB). Solid circles in $\mathrm{E}$ are the average of Year 1 and Year 2. Continual photoperiod treatments consisted of 9-h natural days extended with light from incandescent lamps. NI = 4-h night interruption. Data presented in B, C, D, and E were collected when the first flower opened on each plant. Each symbol is based on 10 observations. Vertical bars represent $95 \%$ confidence intervals, and, when smaller than symbols, are not shown. $\mathrm{Q}^{* * *}=$ quadratic trend significant at $P \leq 0.001$. 


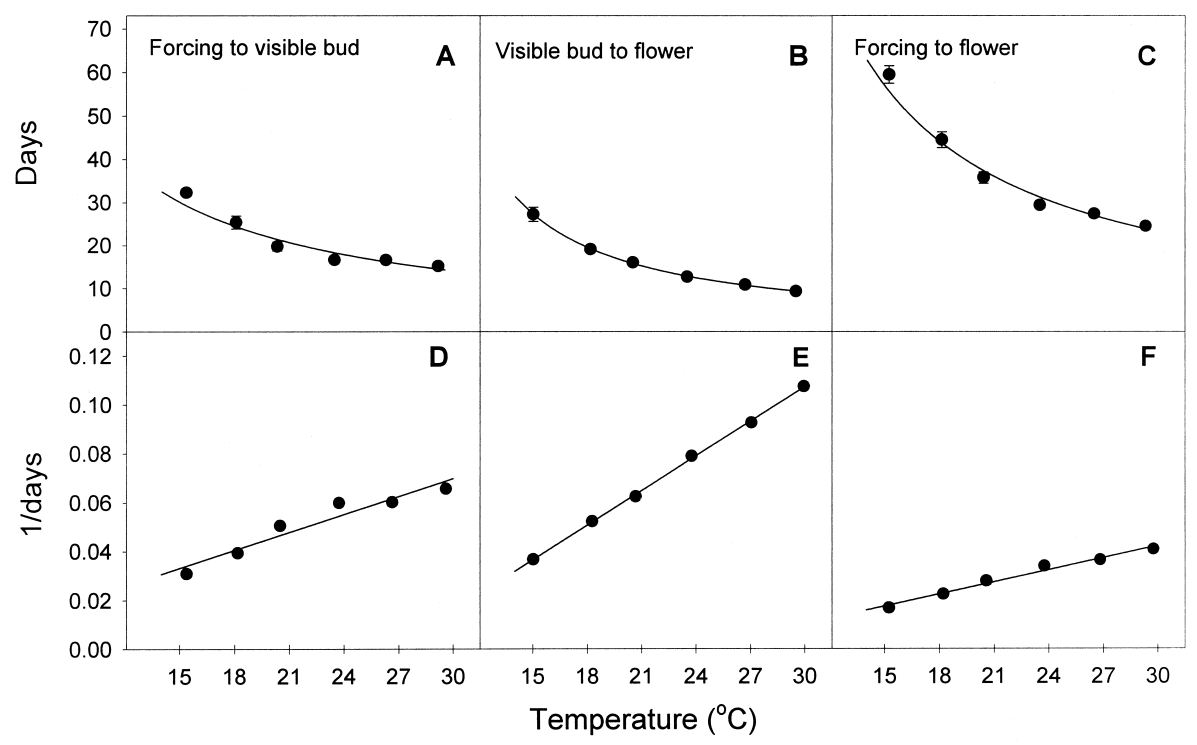

Fig. 3. Effects of growing temperature on (A) time from transplant to visible bud, (B) visible bud to flower, and (C) transplant to flower, and (D) rate of progress toward visible bud, $(\mathbf{E})$ visible bud to flower, and $(\mathbf{F})$ to flower in Oenothera fruticosa 'Youngii-lapsley' (Expt. 3). Each symbol is based on 10 observations. Vertical bars represent $95 \%$ confidence intervals, and, when smaller than symbols, are not shown. Parameters of linear regression lines are presented in Table 3 . The quadratic regression lines in $\mathrm{A}, \mathrm{B}$, and $\mathrm{C}$ are the reciprocals of correlated linear regression lines in $\mathrm{D}, \mathrm{E}$, and $\mathrm{F}$.

photoperiod increased from 16 to $24 \mathrm{~h}$ (Fig. 2A). Days to flower was 40 under NI, a duration similar to that of plants grown under 16-h photoperiods. The time from visible bud to flower was 18 to $20 \mathrm{~d}$ and was unaffected by photoperiod. The number of new nodes produced during forcing decreased linearly from 42 to 27 as photoperiod increased from 10 to $16 \mathrm{~h}$ (Fig. 2B) and was closely correlated with the observed decrease in time to flower $(P=0.003)$.

The number of flowers and buds at first flower decreased markedly as photoperiod increased from 10 to $16 \mathrm{~h}$ (Fig. 2C). There were no difference between number of flowers and buds at $16 \mathrm{~h}$ and $24 \mathrm{~h}$. Plants grown under 10-h photoperiods had over 100 flowers per plant. Under 4 -h NI, there were $\approx 50$ flowers per plant, a number similar to that of plants grown under 16 -h photoperiods.

The number of total lateral shoots decreased with increasing photoperiod (Fig. 2D). About $60 \%$ of the lateral shoots flowered independent of photoperiod (data not shown). The change in the number of lateral shoots under the different photoperiods had a marked effect on plant appearance. Plants grown under photoperiods $\leq 14$ h were leafy and had abundant flowers, while those grown under photoperiods $\geq 14 \mathrm{~h}$ were spindly and had sparse flowers.

20.6 to $\left.29.8^{\circ} \mathrm{C}\right)$.
Measured at first open flower, plants were consistently tallest at 14-h, 24-h, and NI (Fig. $2 \mathrm{E})$, though the absolute differences in height were small. Under NI, height was generally similar to that of plants grown under 14- and 24-h photoperiods. There was no correlation between the number of new nodes and plant height (Fig. 2B and E).

ForCING TEMPERATURE (EXPT. 3). Days to visible bud, days from visible bud to flower, and days to flower decreased as ADT increased (Fig. 3A-C). The plants flowered uniformly and variability for time to visible bud and to flower was fewer than $4 \mathrm{~d}$ at each temperature. An increase from 15.2 to $20.6^{\circ} \mathrm{C}$ accelerated flowering more than an increase from 20.6 to $29.8^{\circ} \mathrm{C}$. For example, time to flower decreased by $24 \mathrm{~d}$ (from 60 to $36 \mathrm{~d}$ ) as temperature increased $5.4{ }^{\circ} \mathrm{C}$ (from 15.2 to $20.6^{\circ} \mathrm{C}$ ), but only by $11 \mathrm{~d}$ (from 36 to 25 ) when temperature increased $9.2{ }^{\circ} \mathrm{C}$ (from

The rate of progress toward visible bud, from visible bud to flowering, and to flowering was highly correlated with temperature (Table 3; Fig. 3D-F). Base temperatures for each developmental stage ranged from 1.5 to $7.3^{\circ} \mathrm{C}$ (Table 3). Oenothera fruticosa required 606 degree-days to flower. The days required to complete a developmental stage can be calculated as degree-days $/\left(\mathrm{T}_{\mathrm{a}}-\mathrm{T}_{\mathrm{b}}\right)$. Differences between predicted and observed time for any developmental stage and temperature were no greater than $5 \mathrm{~d}$ (data not shown).

The number of flowers and buds per plant decreased linearly from over 170 to fewer than 30 as temperature increased from 15.2 to $29.8^{\circ} \mathrm{C}$, an average reduction of nine flowers for every $1{ }^{\circ} \mathrm{C}$ increase (Fig. 4A). Flower diameter decreased from 7 to $4 \mathrm{~cm}$ as temperature increased (Fig. 4B), a threefold difference in flower area (assuming that flower shape is circular). Taken together, there was $\mathrm{a} \approx 20$-fold reduction in flower area per plant when growing temperature was increased from 15.2 to $29.8^{\circ} \mathrm{C}$. Increasing temperature resulted in reduced flower size of Coreopsis grandiflora Hogg ex Sweet. 'Sunray', Leucanthemum $\times$ superbum Bergman ex J. Ingram 'Snowcap', Rudbeckia fulgida Ait. 'Goldsturm' (Yuan et al., 1998), Campanula carpatica 'Blue Clips' (Whitman et al., 1997), Coreopsis verticillata L. 'Moonbeam', Campanula 'Birch Hybrid', and other herbaceous perennials (Frane, 1999).

Height at first flower was $35 \%$ shorter as temperature increased from 15.2 to $23.8^{\circ} \mathrm{C}$ (Fig. 4C). As forcing temperature increased from 23.8 to $29.8^{\circ} \mathrm{C}$, there was almost no further change in plant height.

Table 3. Parameters of linear regression analysis relating forcing temperature to rate of progress from transplant to visible bud (VB), visible bud to flowering (VB to FLW), and transplant to flowering (FLW) for Oenothera fruticosa 'Youngii-lapsley'; intercept and slope were used to calculate base temperature $\left(\mathrm{T}_{\mathrm{b}}\right)$ and degree-days.

\begin{tabular}{|c|c|c|c|c|c|}
\hline $\begin{array}{l}\text { Developmental } \\
\text { stage } \\
\text { (d) }\end{array}$ & $\begin{array}{c}\text { Intercept } \\
\left(\mathrm{b}_{0}\right) \\
1 / \mathrm{d}\end{array}$ & $\begin{array}{c}\text { Slope } \\
\left(\mathrm{b}_{1}\right) \\
(1 / \mathrm{d}) /{ }^{\circ} \mathrm{C}\end{array}$ & $\begin{array}{c}\mathrm{T}_{\mathrm{b}} \\
\left({ }^{\circ} \mathrm{C}\right)\end{array}$ & Degree-days & $r^{2}$ \\
\hline Transplant to VB & $-3.56 \mathrm{E}-3 \pm 7.99 \mathrm{E}-3^{z}$ & $2.45 \mathrm{E}-3 \pm 3.49 \mathrm{E}-4$ & 1.5 & 408 & $0.91^{* * *}$ \\
\hline VB to FLW & $-3.42 \mathrm{E}-2 \pm 1.56 \mathrm{E}-3$ & $4.72 \mathrm{E}-3 \pm 6.77 \mathrm{E}-5$ & 7.3 & 211 & $0.99^{* * * *}$ \\
\hline Transplant to FLW & $-7.21 \mathrm{E}-3 \pm 2.75 \mathrm{E}-3$ & $1.65 \mathrm{E}-3 \pm 1.20 \mathrm{E}-4$ & 4.4 & 606 & $0.97^{\text {**** }}$ \\
\hline
\end{tabular}

zStandard error.

${ }^{* *, * * * *}$ Significant at $P<0.01$ or 0.001 , respectively. 
Plant growth Regulators (Expt. 4). Uniconazole reduced plant height at flower by $31 \%$ compared to the nontreated controls. No other PGR reduced plant height in these experiments. Days to visible bud, days to flower, number of new leaves, or number of flowers was not affected by plant growth regulator application (data not shown). However, flower diameter on plants sprayed with uniconazole was $36 \%$ smaller than that of the controls, which resulted in a 58\% flower area reduction. Although daminozide and chlormequat did not reduce plant height, plants sprayed with these PGRs as well as uniconazole had shorter lateral stems compared with that of control plants. The shorter stems changed the plants' natural conical shape to a cylindrical one. Further studies using different rates and application strategy of uniconazole and perhaps other PGRs individually or in combination are needed to identify PGRs and rates that effectively control height without such a drastic reduction in flower size and change in plant shape.

Flower production was influenced strongly by relatively small increases in light levels. For example, plants vernalized for 15 weeks and grown under natural light with a 16-h photoperiod and supplemental light provided by HPS lamps (Expt. 1) produced 97 flowers, while those in Expt. 2, also vernalized for 15 weeks and provided a 16-h photoperiod with day extension from incandescent lamps, produced only 47 flowers (Year 2). Plants received an estimated 9.0 or $11.6 \mathrm{~mol} \cdot \mathrm{m}^{-2} \cdot \mathrm{d}^{-1}$ of total PAR when given day extension with incandescent lamps or HPS lamps, respectively. Increasing irradiance increased flower number in a number of herbaceous perennial

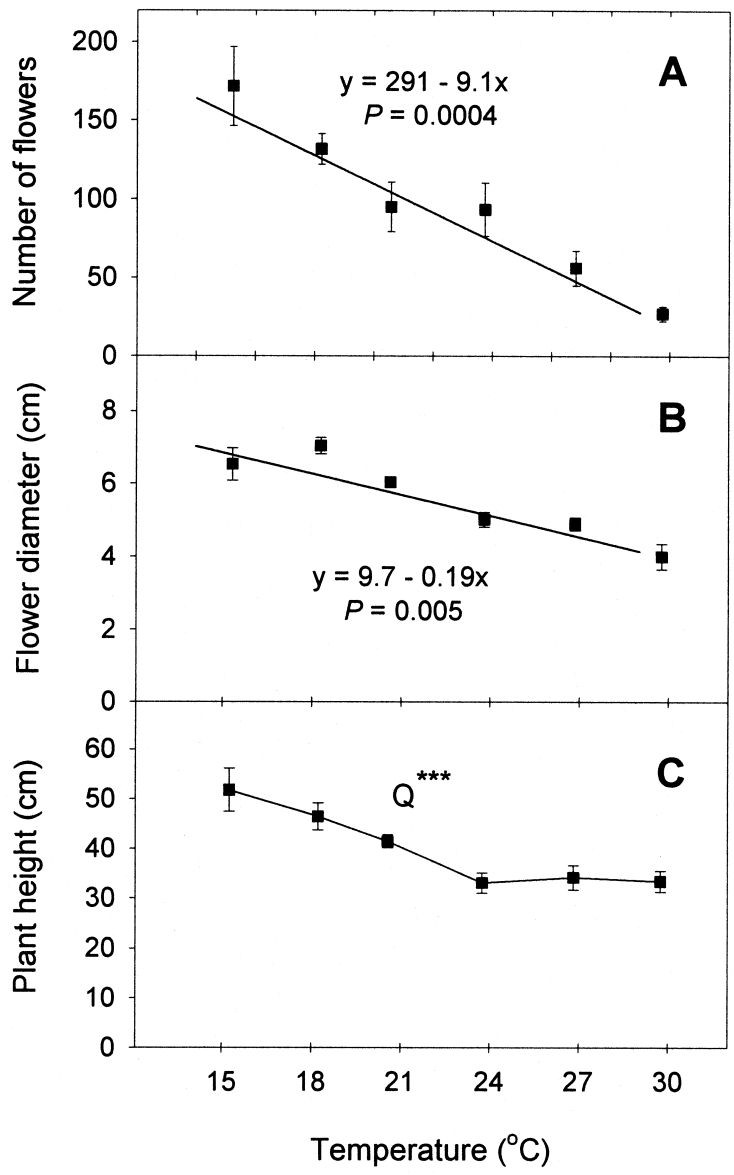

Fig. 4. Effects of forcing temperature on (A) number of flowers and buds, (B) flower diameter, and (C) plant height in Oenothera fruticosa 'Youngii-lapsley' (Expt. 3). All parameters were measured when the first flower opened. Each symbol is based on 10 observations. Vertical bars represent $95 \%$ confidence intervals, and, when smaller than symbols, are not shown. $\mathrm{Q}^{* * *}=$ quadratic trend significant at 0.001 . species (Cameron et al., unpublished). For Dendranthema $\times$ grandiflorum Kitam. 'Resiliance' ('Resiliance' chrysanthemum) grown under a 12-h day, flower number increased from 7.2 to 19.0 as daily light integral increased from 10.4 to $29.9 \mathrm{~mol} \cdot \mathrm{m}^{-2} \cdot \mathrm{d}^{-1}$ (Warrington and Norton, 1991). Total flower area per plant was found to increase also for $D$. × grandiflorum 'Bright Golden Anne' as $P P F$ increased (Karlsson and Heins, 1986).

Oenothera fruticosa 'Youngii-lapsley' performed well indoors in preliminary postharvest trials, and floral display was acceptable for $20 \mathrm{~d}$. Although each flower lasted only 2 to $3 \mathrm{~d}$, new flowers opened even under low interior light. After interior evaluation, the same plants were planted outdoors in a trial garden and have overwintered with no losses and flowered well (data not shown).

In summary, Oenothera fruticosa 'Youngii-lapsley' has great potential as a potted flowering ornamental plant. Horticulturally, it is a facultative long-day plant with an obligate vernalization requirement, the only Oenothera reported to have this combination of requirements. Flowering occurred consistently after a minimum 3week vernalization treatment, delivered to 18-node plants in plugs trays followed by any photoperiod $\geq 10 \mathrm{~h}$. Oenothera fruticosa 'Youngii-lapsley' flowered under all tested photoperiods, but flowering was accelerated by $\approx 2$ weeks under the longer photoperiods. Though slower to flower, plants were most attractive and better suited as potted plants when grown under photoperiods $\leq 14 \mathrm{~h}$ with ample light because of the higher numbers of vegetative and flowering lateral shoots. For forcing plants, an ADT between 17 and $20^{\circ} \mathrm{C}$ is probably optimal to reduce production time with a minimal in quality reduction. Plants will be ready to market in 50 to $60 \mathrm{~d}$ by using these production conditions. Uniconazole at $15 \mathrm{mg} \cdot \mathrm{L}^{-1}$ can be used to reduce plant height $\approx 30 \%$ but also will decrease flower diameter by $36 \%$. A production protocol has been developed for $O$. fruticosa 'Youngii-lapsley' based largely on the results of this study (Clough et al., 1999).

\section{Literature Cited}

Chouard, P. 1960. Vernalization and its relation to dormancy. Annu. Rev. Plant Physiol. 11:191-238.

Clough, E.A., A.C. Cameron, R.D. Heins, and W.H. Carlson. 1999. Forcing perennials crop by crop. Species: Oenothera fruticosa 'Youngii-lapsley'. Greenhouse Grower 17(10):50-60.

Frane, A.J. 1999. Temperature effects on timing and bud development of Coreopsis verticillata 'Moonbeam' and flower induction of long-day perennials under different night temperatures. MS thesis, Michigan State Univ., East Lansing.

Griffiths, M. 1994. Index of garden plants. Timber Press, Portland, Ore.

Iversen, R.R. and T.C. Weiler. 1994. Strategies to force flowering of six herbaceous garden perennials HortTechnology 4:61-65.

Karlsson, M.G. and R.D. Heins. 1986. Response surface analysis of flowering in Chrysanthemum 'Bright Golden Anne'. J. Amer. Soc. Hort. Sci. 111:253-259.

Knapp, R. 1957. Über die Beeinflussung von Eigenschaften der Blüten und Infloreszenzen durch die Temperatur. Naturwissenschaften 44:383.

Lang, A. 1965. Physiology of flower initiation, p. 1380-1535. In: W. Ruhland (ed.). Encyclopedia of plant physiology. vol. 15(1). Springer-Verlag, Berlin.

Maginnes, E.A. and R.W. Langhans. 1961. The effect of photoperiod and temperature on initiation and flowering of snapdragon (Antirrhinum majus-variety Jackpot). J. Amer. Soc. Hort. Sci. 77:600-607.

Nau, J. 1996. Ball perennial manual: Propagation and production. Ball, Batavia, Ill.

Picard, C. 1965. Contribution a la connaissance de la vernalisation, de ses particularités et de sa signfication chez Oenothera biennis L. var. Sulfurea De Vries. Ann. Sci. Naturelles, Bot. 6:197-314.

Pickard, C. 1967. Action du CCC et du B 995 sur la mise à fleur d'une plante bisannuelle, l'Oenothera biennis. Planta 74:302-312.

Roberts, E.H. and R.J. Summerfield. 1987. Measurement and prediction of flowering in annual crops, p. 17 50. In: J.G. Atherton (ed.). Manipulation of flowering. Butterworths, London.

Runkle, E.S., R.D. Heins, A.C. Cameron, and W.H. Carlson. 1998. Flowering of Leucanthemum $\times$ superbum 'Snowcap' in response to photoperiod and cold treatment. HortScience 33:1003-1006.

Takimoto, A. 1985. Oenothera, p. 231-236. In: A.H. Halevy (ed.). CRC handbook of flowering, vol. 5. CRC Press, Boca Raton, Fla.

Vince-Prue, D. 1975. Vernalization and photoperiodism in plants. McGraw Hill, London.

Warrington, I.J. and R.A. Norton. 1991. An evaluation of plant growth and development under various daily quantum integrals. J. Amer. Soc. Hort. Sci. 116:544-551.

Whitman, C.M., R.D. Heins, A.C . Cameron, and W.H. Carlson. 1996. Cold treatments, photoperiod, and forcing temperature influence flowering of Lavandula angustifolia. HortScience 31:1150-1153.

Whitman, C.M., R.D. Heins, A.C. Cameron, and W.H. Carlson. 1997. Cold treatment and forcing temperature influence flowering of Campanula carpatica 'Blue Clips'. HortScience 32:861-865.

Wiesner, M.B. 1991. Enchanted evenings: Get to know Oenothera and dusk may be your favorite time of day. Amer. Hort. 70:16-21.

Yuan, M., W.H.Carlson, R.D. Heins, and A.C. Cameron. 1998. Effect of forcing temperature on time to flower of Coreopsis grandiflora, Gaillardia $\times$ grandiflora, Leucanthemum $\times$ superbum, and Rudbeckia fulgida. HortScience 33:663-667. 